\title{
PENGUKURAN KINERJA KEUANGAN PERUSAHAAN KOMPAS 100
} PERIODE 2015-2018

\author{
Debriana Anggita A.S,1) \\ debrianaanggitaayusafitri@gmail.com \\ Universitas Pembangunan Nasional Veteran Jawa Timur \\ Yuniningsih Yuniningsih2) \\ yuniningsih@upnjatim.ac.id \\ Universitas Pembangunan Nasional Veteran Jawa Timur
}

\begin{abstract}
Abstrak
Penelitian ini bertujuan untuk mengetahui pengaruh aktivitas, leverage, likuiditas dan pengelolaan biaya terhadap kinerja keuangan pada perusahaan yang tergabung dalam Indeks Kompas 100 periode 2015-2018. Penelitian ini menggunakan data sekunder, berupa laporan keuangan tahunan dan performa perusahaan dari 27 perusahaan Kompas 100 selama periode 2015-2018. Sampel perusahaan diperoleh dengan metode purposive sampling. Alat analisis yang digunakan adalah regresi linear berganda, uji asumsi klasik, uji $t$, uji $F$, dan koefisien determinasi $\left(R^{2}\right)$ dengan aktivitas, leverage, likuiditas, dan pengelolaan biaya sebagai variabel independen, dan kinerja keuangan sebagai variabel dependen. Hasil penelitian menunjukkan bahwa secara parsial aktivitas dan leverage berpengaruh signifikan dengan nilai signifikan masing-masing sebesar 0,041 dan 0,098. Sedangkan likuiditas dan pengelolaan biaya tidak berpengaruh signifikan dengan nilai signifikan masing-masing sebesar 0,19 dan 0,156. Sementara itu secara simultan aktivitas, leverage, likuiditas, dan pengelolaan biaya berpengaruh signifikan dengan nilai signifikan sebesar 0,019.
\end{abstract}

Kata Kunci: aktivitas, kinerja keuangan, leverage, likuiditas, pengelolaan biaya.

\section{Pendahuluan}

Dalam menginvestasikan dananya, para investor sangat bergantung pada informasi perusahaan mengenai kinerja keuangan. Jumingan (2006:239) dalam Pohan, S (2017) menjelaskan kinerja keuangan merupakan gambaran kondisi keuangan perusahaan pada suatu periode yang menyangkut aspek penghimpunan dana maupun penyalurannya yang diukur dengan indikator kecukupan modal, likuiditas, dan profitabilitas. Kinerja keuangan yang baik akan berdampak pada kepercayaan para investor untuk menanamkan dananya dengan menjual saham perusahaan kepada masyarakat melalui pasar modal (Dewanti, W R. 2016).

Kinerja keuangan dapat diukur dengan tiga rasio yaitu profitabilitas, pertumbuhan, dan nilai pasar (Yuniningsih, 2018). Pengukuran kinerja keuangan dengan rasio nilai pasar (market value rasio) dapat menggunakan Price Eearning Ratio (PER). PER merupakan salah satu rasio yang digunakan untuk mengukur kinerja saham perusahaan berdasarkan perbandingan harga saham dengan laba per lembar sahan (Sulistyastuti, 2005).

Price Earning Ratio diukur dengan rasio aktivitas, leverage, likuiditas, dan pengelolaan biaya. Rasio aktivitas merupakan rasio yang digunakan untuk mengukur seberapa efisiensinya perusahaan dalam memanfaatkan sumber daya yang ada pada perusahaan (Elaga, M P; et.al. 2018). Rasio leverage merupakan rasio yang digunakan untuk mengukur seberapa besar beban utang yang ditanggung oleh perusahaan dibandingkan dengan aktivanya (Kasmir, 2011:151; Rizki, N. 2015). Yuniningsih (2018:53) menjelaskan likuiditas adalah rasio yang digunakan untuk mengukur kemampuan perusahaan dalam memenuhi kewajiban yang akan jatuh tempo dengan melihat sejauh mana arus kas operasi dapat menutupi kebutuhan keuangannya guna memenuhi 
kewajiban (hutang). Pengelolaan biaya merupakan hal yang penting bagi sebuah perusahaan guna menunjang kegiatan operasionalnya. Mulyadi (2005:8) dalam Kuswita, D I (2014) menjelaskan biaya adalah pengorbanan ekonomis dalam satuan yang telah terjadi, sedang terjadi, atau kemungkinan akan terjadi untuk suatu tujuan tertentu.

Penelitian yang dilakukan oleh Dewanti, W R (2016) menunjukkan hasil penelitian aktivitas berpengaruh terhadap kinerja keuangan. Sedangkan hasil tersebut berbanding terbalik dengan penelitian yang dilakukan oleh Sitepu, et.al (2013) yang menunjukkan hasil bahwa aktivitas tidak berpengaruh signifikan terhadap kinerja keuangan. Penelitian yang dilakukan oleh Halim (2005) menunjukkan bahwa leverage memiliki pengaruh yang positif terhadap kinerja keuangan. Namun tidak dengan penelitian yang dilakukan oleh Dewanti, W R (2016) menunjukkan hasil yang berbanding terbalik yaitu leverage tidak berpengaruh terhadap kinerja keuangan.

Penelitian yang dilakukan oleh Lusiana, F W (2010) mengatakan bahwa likuiditas memiliki pengaruh yang signifikan terhadap kinerja keuangan. Sedangkan hasil penelitian dari Dewanti, W R (2016) memiliki hasil yang berbanding terbalik yaitu likuiditas tidak berpengaruh positif terhadap kinerja keuangan. Penelitian yang dilakukan oleh Indahsafitri, P N (2018) menyatakan bahwa pengelolaan biaya memiliki pengaruh signifikan dan berpengaruh positif terhadap kinerja keuangan. Hasil tersebut berbanding terbalik dengan penelitian yang dilakukan oleh Hidayah, N (2018) yaitu menunjukkan secara parsial pengelolaan biaya berpengaruh positif tidak signifikan terhadap kinerja keuangan sedangkan secara simultan pengelolaan biaya berpengaruh signifikan terhadap kinerja keuangan.

\section{Tinjauan Teori}

\subsection{Kinerja Keuangan}

Kinerja keuangan merupakan cerminan kondisi kesehatan perusahaan yang diperoleh dari pengukuran sumber daya perusahaan secara efektif dan efisien. Menurut Sawir, A (2005) dalam Solikhah (2010) yang dikutip oleh Kusumo, B P (2012) menjelaskan kinerja keuangan merupakan suatu gambaran dari kondisi keuangan sebuah perusahaan. Penilaian kinerja keuangan bertujuan untuk mengukur tingkat biaya pada berbagai kegiatan perusahaan, mengukur efisiensi dari bagian produksi, menentukan tingkat keuntungan perusahaan, menilai hasil kerja setiap individu, dan juga untuk menentukan perlu atau tidaknya menggunakan kebijakan yang baru dalam mencapai hasil yang lebih baik lagi untuk ke depannya (Munawir. 2002; Wild dan Halsey. 2005).

\subsection{Price Earning Ratio (PER)}

Dalam analisis fundamental, PER merupakan bagian dari rasio nilai pasar yang digunakan untuk mengevaluasi laporan keuangan. Menurut Sulistyastuti (2005) PER adalah rasio yang digunakan untuk mengukur kinerja saham yang didasarkan pada perbandingan harga saham dengan laba per lembar saham. Nilai PER selalu berubahubah mengikuti pergerakan saham. Nilai PER yang semakin tinggi menunjukkan harga saham semakin mahal. Tetapi jika nilai PER semakin kecil maka hal tersebut menunjukkan harga saham perusahaan semakin murah (Hadi, N. 2013:82; Dewanti, W R. 2016). 


\subsection{Aktivitas}

Aktivitas pada dasarnya digunakan untuk mengukur tingkat efisiensi perusahaan dalam memanfaatkan sumber daya yang dimiliki perusahaan (Elaga, M P; et.al. 2018). Rasio aktivitas diukur dengan membandingkan antara tingkat penjualan perusahaan dengan investasi yang berada dalam aktiva (Kasmir. 2008). Penggunaan rasio aktivitas tidak hanya untuk mengetahui kondisi keuangan perusahaan, tetapi dapat digunakan untuk mengukur kinerja manajemen dalam menjalankan perusahaan guna mencapai target yang telah ditentukan. Rasio aktivitas ini dapat diukur dengan Total Asset Turnover (TATO) yang menunjukkan tingkat efisiensi perusahaan ditinjau dari penggunaan keseluruhan aktiva dalam menghasilkan target volume penjualan (Lukman. 2011:62; Dewanti, W R. 2016).

H1 : $\quad$ Aktivitas berpengaruh positif terhadap Kinerja Keuangan

\subsection{Leverage}

Leverage merupakan rasio yang digunakan untuk mengukur seberapa besar perusahaan dibiayai oleh utang (Fahmi. 2014; Maharani, F R. 2018). Kasmir (2011:151) dalam Rizki, N (2015) menjelaskan leverage adalah rasio yang digunakan untuk mengukur seberapa besar beban utang yang ditanggung oleh perusahaan dibandingkan dengan aktivanya. Semakin besar nilai rasio leverage suatu perusahaan, maka akan semakin besar risiko kegagalan perusahaan dan begitu sebaliknya (Margareta dan Nurmayanti. 2009; Maharani, F R. 2018). Rasio leverage dapat diukur dengan Debt to Equity Ratio (DER) yang menurut Kasmir (2010) dalam penelitian Dewanti, W R (2016) adalah rasio yang digunakan untuk menunjukkan cerminan kemampuan perusahaan dalam memenuhi kewajibannya yang ditinjau dari seberapa besar bagian dari ekuitas digunakan untuk membayar utang.

H2 : $\quad$ Leverage berpengaruh negatif terhadap Kinerja Keuangan

\subsection{Likuiditas}

Likuiditas merupakan rasio yang digunakan untuk mengukur kemampuan perusahaan dalam memenuhi kewajiban lancarnya dengan meninjau sejauh mana arus kas operasi dapat menutupi kebutuhan keuangannya (Yuniningsih, 2018:53). Semakin tinggi tingkat likuiditas perusahaan menunjukkan kemampuan perusahaan dalam melunasi utang jangka pendeknya semakin tinggi (Harmono, 2001:106). Likuiditas dapat diukur dengan Current Ratio (CR) yang menurut Husnan, S (2013:562) dalam Aulia, N S (2018) adalah rasio yang mengukur seberapa jauh kemampuan perusahaan dalam menggunakan aktiva lancar untuk memenuhi kewajiban lancarnya.

H3 : Likuiditas berpengaruh positif terhadap Kinerja Keuangan

\subsection{Pengelolaan Biaya}

Suatu perusahaan diharuskan dapat mengelola biaya guna menunjang kegiatan operasionalnya karena biaya merupakan komponen yang sangat penting bagi perusahaan dan menjadi faktor dari tercapainya tujuan perusahaan. Maulana, I (2016) mengutip Simamora, H (2006) biaya adalah kas yang dikorbankan agar dapat memberikan manfaat bagi perusahaan pada saat ini atau dimasa yang akan datang. Salah satu indikator yang dapat digunakan dalam mengukur pengelolaan biaya adalah Gross Profit Margin (GPM). Kasmir (2015:199) dalam Nurlaelah, et.al (2017) menjelaskan rasio profit margin merupakan salah satu rasio yang digunakan untuk mengukur margin laba perusahaan atas penjualan. GPM yang meningkat menunjukkan kemampuan perusahaan yang baik dalam menutupi biaya administrasi, penyusutan, dan beban bunga atas hutang dan pajak.

H4 : Pengelolaan Biaya berpengaruh positif terhadap Kinerja Keuangan 
3. Kerangka Konseptual

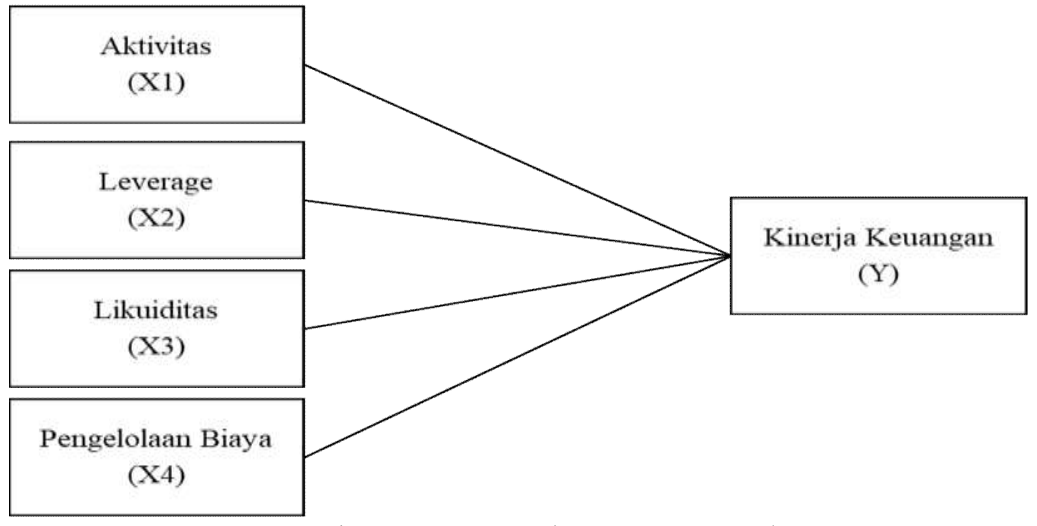

Gambar 1. Kerangka Konseptual

\section{Metode Penelitian}

\subsection{Metode Penelitian}

Penelitian ini menggunakan metode penelitian asosiatif (hubungan). Penelitian asosiatif merupakan penelitian yang memiliki tujuan untuk mengetahui pengaruh atau hubungan antara dua variabel atau lebih (Uno, M B; et.al. 2014).

\subsection{Sumber Data}

Jenis data yang digunakan adalah data sekunder yang berupa data untuk semua variabel yaitu aktivitas, leverage, dan pengelolaan biaya yang diperoleh dari situs www.idx.co.id dan www.emiten.kontan.co.id. Data yang digunakan berupa laporan keuangan tahunan dan performa perusahaan untuk periode 2015-2018 pada perusahaan Kompas 100.

\subsection{Pengumpulan Data}

Metode yang digunakan dalam mengumpulkan data adalah dokumentasi. Metode dokumentasi adalah suatu cara yang digunakan untuk mengumpulkan data, informasi, dan dokumen perusahaan yang sesuai dengan penelitian (Sugiyono. 2013).

\subsection{Pemilihan Sampel}

Populasi dalam penelitian ini adalah semua perusahaan yang tergabung dalam indeks Kompas 100 dengan periode pengamatan 2015-2018 yang berjumlah 153 perusahaan. Metode yang digunakan dalam pengambilan sampel berupa purposive sampling yaitu teknik sampling yang didasarkan pada karakteristik tertentu yang dianggap memiliki hubungan dengan karakteristik populasi yang diketahui (Sugiyono. 2013). Adapun kriteria dalam memilih sampel untuk penelitian ini sebagai berikut:

a. Perusahaan yang tergabung dalam Indeks Kompas 100 tercatat selama periode 2015-2018.

b. Perusahaan yang tergabung dalam Indeks Kompas 100 memiliki laporan keuangan lengkap periode 2015-2018 terkait dengan variabel yang dibutuhkan.

Berdasarkan kriteria tersebut, terpilih sebanyak 27 perusahaan sebagai sampel dengan kurun waktu 4 tahun. Sehingga jumlah data observasi pada penelitian ini adalah 108. 


\subsection{Teknik Analisis dan Uji Hipotesis}

Teknik analisis yang digunakan adalah analisis regresi linear berganda dengan persamaan sebagai berikut: (Prihardi, R P. 2016)

Keterangan:

$$
Y=b_{0}+b_{1} X_{1}+b_{2} X_{2}+b_{3} X_{3}+b_{4} X_{4}+e
$$

Y : Kinerja Keuangan

$\mathrm{X}_{1} \quad$ : Aktivitas

$\mathrm{X}_{2} \quad$ : Leverage

$\mathrm{X}_{3} \quad$ : Likuiditas

$\mathrm{X}_{4} \quad$ : Pengelolaan Biaya

$\mathrm{b}_{0} \quad$ : Konstanta

$b_{1}, b_{2}, b_{3}, b_{4}$ : Koefisien regresi dari setiap variabel independen

e : Variabel Pengganggu, diasumsikan 0

Sebelum melakukan uji hipotesis maka dilakukan uji asumsi klasik terlebih dahulu yaitu uji normalitas, uji multikolinearitas, uji heteroskedastisitas, dan uji autokorelasi. Uji hipotesis yang digunakan adalah uji simultan (uji F), uji parsial (uji t), dan analisis koefisien determinasi (R2).

5. Hasil

\subsection{Uji Normalitas}

Hasil uji normalitas menunjukkan Asymp. Sig variabel Aktivitas (TATO), Leverage (DER), Likuiditas (CR), dan Pengelolaan Biaya (GPM) lebih kecil dari 0,05 (5\%) yang berarti bahwa data tidak berdistribusi normal. Tetapi berdasarkan uji kualitas data memiliki kualitas yang baik dan dapat dilanjutkan untuk diolah lebih lanjut.

\subsection{Uji Multikolinearitas}

Hasil uji multikolinearitas menunjukkan bahwa tidak ada gejala multikolinearitas dikarenakan nilai VIF pada variabel lebih kecil dari 10. Syarat terjadi multikolineartitas tinggi jika nilai VIF lebih besar dari 10.

\subsection{Uji Heteroskedastisitas}

Hasil uji heteroskedastisitas menunjukkan bahwa pada variabel Aktivitas (TATO), Leverage (DER), Likuiditas (CR), dan Pengelolaan Biaya (GPM) tidak memiliki korelasi yang signifikan residual dengan variabel bebasnya. Jadi dapat disimpulkan bahwa tidak terjadi heteroskedastisitas dan memenuhi asumsi heteroskedastisitas.

\subsection{Uji Autokorelasi}

Hasil uji autokorelasi menunjukkan nilai Durbin Watson sebesar 2,217 angka berada di daerah tidak ada autokorelasi positif maupun negatif yang menunjukkan tidak ada gejala autokorelasi.

\subsection{Uji Simultan (Uji F)}

Hasil uji F menunjukkan hasil yang signifikan dengan tingkat signifikan sebesar 0,019. Maka dapat disimpulkan bahwa alat analisis regresi berganda yang digunakan adalah tepat.

\subsection{Uji Parsial (Uji T)}

1. Aktivitas berpengaruh negatif signifikan terhadap Kinerja Keuangan

2. Leverage berpengaruh negatif signifikan terhadap Kinerja Keuangan

3. Likuiditas tidak berpengaruh negatif dan tidak signifikan terhadap Kinerja Keuangan

4. Pengelolaan Biaya tidak berpengaruh positif dan tidak signifikan terhadap Kinerja Keuangan 


\subsection{Koefisien Determinasi $\left(\mathbf{R}^{2}\right)$}

Hasil uji koefisien determinasi (R2) menunjukkan signifikan positif yang terlihat dari angka Fhitung = 3,121 dengan Sig. 0,019 < 0,1 yang berarti perubahan keempat variabel aktivitas (X1), leverage (X2), likuiditas (X3), dan pengelolaan biaya (X4) mampu menjelaskan perubahan variabel Kinerja Keuangan yang diukur menggunakan PER (Y).

\section{Pembahasan}

Hasil penelitian menunjukkan bahwa aktivitas yang diukur dengan TATO berpengaruh negatif signifikan terhadap kinerja keuangan yang diukur dengan PER. Hal ini menunjukkan aktivitas perusahaan naik tetapi kinerja keuangan perusahaan turun dan disebabkan oleh penjualan yang dilakukan kemungkinan dilakukan secara kredit. Penjualan secara kredit membutuhkan pendanaan perusahaan yang diambilkan dari hutang perusahaan. Hasil penelitian menunjukkan bahwa leverage yang diukur dengan DER berpengaruh negatif signifikan terhadap kinerja keuangan yang diukur dengan PER yang berarti nilai DER yang tinggi menyebabkan kinerja keuangan perusahaan turun dan dikarenakan utang perusahaan yang tinggi guna menutupi biaya operasional perusahaan. Ketika hutang perusahaan lebih tinggi dibandingkan dengan kas yang diterima oleh perusahaan, maka akan menurunkan kinerja keuangan perusahaan.

Hasil penelitian menunjukkan bahwa likuiditas yang diukur dengan CR tidak berpengaruh signifikan terhadap kinerja keuangan yang diukur dengan PER. Hal tersebut menunjukkan tingkat likuiditas perusahaan kompas 100 tidak baik karena penjualan yang dilakukan secara kredit menyebabkan alokasi kas pada aktiva lancar kurang dan lebih dialokasikan pada hutang. Hasil penelitian menunjukkan bahwa pengelolaan biaya yang diukur dengan GPM tidak berpengaruh signifikan terhadap kinerja keuangan yang diukur dengan PER. Artinya laba perusahaan yang digunakan untuk mendanai kegiatan operasional dialokasikan pada piutang perusahaan bukan pada kas sehingga menyebabkan kas pada perusahaan lebih kecil daripada piutang.

\section{Kesimpulan Dan Saran}

\subsection{Kesimpulan}

1. Aktivitas yang diukur dengan Total Asset Turnover (TATO) berpengaruh negatif signifikan terhadap kinerja keuangan yang berarti aktivitas memberikan kontribusi terhadap kinerja keuangan perusahaan kompas 100. Maka hasil penelitian menunjukkan bahwa tinggi rendahnya aktivitas perusahaan dapat mempengaruhi kinerja keuangan perusahaan kompas 100.

2. Leverage yang diukur dengan Debt to Equity Ratio (DER) berpengaruh negatif signifikan terhadap kinerja keuangan yang berarti semakin rendah utang perusahaan maka kinerja keuangan akan semakin baik, begitu sebaliknya dan juga leverage memberikan kontribusi terhadap kinerja keuangan perusahaan kompas 100. Maka hasil penelitian menunjukkan bahwa tinggi rendahnya leverage perusahaan dapat mempengaruhi kinerja keuangan perusahaan kompas 100.

3. Likuiditas yang diukur dengan Current Ratio (CR) tidak berpengaruh negatif signifikan terhadap kinerja keuangan yang berarti likuiditas tidak memberikan kontribusi terhadap kinerja keuangan perusahaan kompas 100. Maka hasil penelitian menunjukkan tinggi rendahnya tingkat likuiditas perusahaan tidak mempengaruhi kinerja keuangan perusahaan kompas 100.

4. Pengelolaan Biaya diukur dengan Gross Profit Margin (GPM) tidak berpengaruh positif terhadap kinerja keuangan yang berarti pengelolaan biaya tidak memberikan kontribusi terhadap kinerja keuangan perusahaan kompas 100. Maka hasil penelitian menunjukkan tinggi rendahnya pengelolaan biaya tidak mempengaruhi kinerja keuangan perusahaan kompas 100. 


\subsection{Saran}

1. Perusahaan diharapkan dapat meminimalisir penjualan secara kredit. Penjualan secara kredit dapat mempengaruhi kas lancar dan tingkat utang perusahaan.

2. Peneliti selanjutnya diharapkan mampu menambahkan sampel dan variabel-variabel lain yang sekiranya berkaitan dengan pengukuran kinerja keuangan perusahaan.

\section{Daftar Pustaka}

Aulia, Nivika Sherin. 2018. Pengaruh CurrentRatio, Leverage, Dan Return On Equity Terhadap Price Earning Ratio Pada Perusahaan Paper And Allied Products Yang Terdaftar Di BEI. Skripsi. Universitas Muria Kudus.

Dewanti, Wenny Rizky. 2016. Pengaruh Current Ratio, Debt To Equity Ratio, Total Asset Turnover, dan Net Profit Margin Terhadap Price Earning Ratio (Studi Empiris pada Perusahaan Industri Barang Konsumsi yang Terdafatar di Bursa Efek Indonesia Periode 2012-2015). Skripsi. Universitas Negeri Yogyakarta.

Elaga, M Panji; S, Wahyu Agung Dandi; P, M Krisna Agung. 2018. Analisis Rasio Aktivitas Untuk Menilai Kinerja Keuangan Pada PT Hanjaya Mandala Sampoerna Tbk. Sriwijaya Internasional. Journal Of Dynamic Economics and Business. Vol. 2 No. 4.

Indahsafitri, Putri Nur; Wahono, B; Khoirul, M. 2018. Pengaruh Return On Equity (ROE), Net Profit Margin (NPM), Gross Profit Margin (GPM), Dan Earning Per Share (EPS) Terhadap Harga Saham (Studi Empiris Pada Perusahaan Yang Terdaftar Dalam LQ 45 BEI Periode 2013-2016). E-Jurnal Riset Manajemen.

Kuswita, Delliana Irene. 2014. Perhitungan Harga Pokok Produksi PT. Erindo Utama Prigen Pasuruan (Aquase). Skripsi. STIE Perbanas Surabaya.

Lusiana, Farida Wahyu. 2010. Analisis Pengaruh Rasio Likuiditas,Rasio Solvabilitas, Rasio Aktivitas, dan Rasio Profitabilitas Terhadap Price Earninng Rasio Pada Perusahaan Manufaktur Yang Terdaftar Di Bursa Efek Indonesia. Skripsi. Universitas Diponegoro Semarang.

Maharani, Fatiha Rachmalita. 2018. Pengaruh Rasio Leverage, Interest Coverage Rasio Dan Jaminan Terhadap Peringkat Obligasi Perusahaan BUMN Bidang Konstruksi Yang Terdaftar di Bursa Efek Indonesia Tahun 2012-2016. Skripsi. Universitas Negeri Yogyakarta.

Mastuti, Nivoresita. 2013. Analisis Pengaruh Price Earning Ratio (PER), Price Book Value (PBV), dan Debt To Equity Ratio (DER) Terhadap Return Saham Perusahaan Sektor Pertambangan. Skripsi. STIE Perbanas Surabaya.

Nurlaelah; Purnama, Sri Intan; Novitasari. 2017. Pengaruh Gross Profit Margin (GPM) Dan Return On Equity (ROE) Terhadap Market Value Pada Perusahaan Sub Sektor Makanan Dan Minuman Yang Terdaftar Di BEI Tahun 2012-2016. Jurnal Studi Akuntansi dan Bisnis. Vol. 5 No. 1.

Pohan, Safriadi. 2017. Analisis Laporan Keuangan Untuk Mengukur Kinerja Keuangan Pada Perusahaan Yang Go Publik Di Bursa Efek Indonesia (Studi Kasus Pada PT. Tiga Pilar Sejahtera Food, Tbk Periode 2011-2015). Jurnal Mantik Penusa. Vol. 1 No. 1.

Rizki, Novita. 2015. Pengaruh Rasio Likuiditas Dan Rasio Leverage Terhadap Tingkat Pertumbuhsn Laba Pada Perusahaan Agribisnis Dan Perkebunan Yang Terdaftar Di Bursa Efek Indonesia Periode 2010-2013. Skripsi. STIE Ekuitas.

Sugiyono. 2013. Metode Penelitian Pendekatan (Pendekatan Kuantitatif, Kualitatif dan R\&D). Bandung: Alfabeta.

Yuninigsih. 2018 .Dasar - Dasar Manajemen Keuangan. Penerbit Indomedia Pustaka. 
Sumber lain:

https:// www.pelajaran.co.id/2017/26/pengertian-tujuan-pengukuran-dan-penilaian kinerja-keuangan.html

https://www.dictio.id/t/apa-yang-dimaksud-dengan-nilai-pasar-atau-marketvalue $/ 14127 / 2$

https:// www.kompasiana.com/disariska/565c79f8349373cd048b459f/bagaimana-debt-toequity-ratio-menjadi-tolak-ukur-kinerja-keuangan?page=all 